\title{
INVESTIGACIÓN
}

\section{Interactions in interesterified palm and palm kernel oils mixtures. I-Solid fat content and consistency}

\section{By Renato Grimaldi ${ }^{1 *}$, Lireny Aparecida Guaraldo Gonçalves ${ }^{1}$, Luiz Antonio Gioielli ${ }^{2}$ and Ilka S. Simões ${ }^{2}$}

\author{
'Laboratório de Óleos e Gorduras - Faculdade de Engenharia de Alimentos (FEA) - \\ Universidade Estadual de Campinas (UNICAMP), Caixa Postal 6091, CEP 13081-970, \\ Campinas , SP, Brazil. E-mail: grimaldi@fea.unicamp.br \\ ${ }^{2}$ Faculdade de Ciências Farmacêuticas - Universidade de São Paulo (USP). \\ E-mail: lagio@usp.br
}

\section{RESUMEN}

Interacciones entre mezclas de aceites de palma y palmiste interesterificados. I-Contenido de grasa solida y consistencia.

Se interesterificaron, en el laboratorio, mezclas de aceite de palma (PO) y aceite de palmiste (PKO): 100/0, 80/20, 60/40, $50 / 50,40 / 60,20 / 80$ y $0 / 100$ en condiciones predefinidas $(0.4 \%$ metóxido de sodio, 20 minutos, $100^{\circ} \mathrm{C}$ ). Las catorce muestras fueron caracterizadas antes y después de la interesterificación por su contenido de grasa sólida (SFC) y su consistencia. Los resultados mostraron la presencia de un sistema eutéctico en las mezclas de $\mathrm{PO}$ y $\mathrm{PKO}$, principalmente en las proporciones 80/20, $60 / 40$ y 50/50, demostrado por los diagramas de isosólidos y de isoconsistencia. La incompatibilidad entre los aceites disminuyó después de la interesterificación y la plasticidad de las mezclas mejoró, hecho demostrado por el incremento del contenido de sólidos y del límite de fluidez a temperatura ambiente.

PALABRAS-CLAVE: Aceite de palma - Aceite de palmiste Consistencia - Contenido de grasa sólida - Interesterificación química.

\section{SUMMARY}

Interactions in interesterified palm and palm kernel oils mixtures. I-Solid fat content and consistency.

Palm oil (PO) and palm kernel oil (PKO) compositions (100/0, $80 / 20,60 / 40,50 / 50,40 / 60,20 / 80$ and $0 / 100$ ) were interesterified in laboratory scale under predetermined conditions $(0.4 \%$ sodium metoxide, 20 minutes, $100^{\circ} \mathrm{C}$ ). The fourteen samples, before and after interesterification, were characterized by solid fat content (SFC) and consistency. Results showed a presence of eutectic system at PO and PKO compositions, mainly at 80/20,60/40 and $50 / 50$ fractions, proved through isosolids and isoconsistency diagrams. The incompatibility among the oils was decreased after reaction and improved the composition plasticity, demonstrated by the increment of solids value and yield value at room temperature.

KEY-WORDS: Chemical interesterification - Consistency - Solid fat content - Palm kernel oil - Palm oil.

\section{INTRODUCTION}

The chemical interesterification is an important tool to modify the compositions of fats and oils. The performance of final product of hydrogenated oils and fats is due the physical alterations in the fatty acids (trans isomers). The interesterification does not modify the profile of the starting raw material. The modifications in the melting and solidification properties of interesterified oils and fats are due to relative proportions of acylglyceride components after fatty acids re-arrangement (Erickson, 1995).

The interesterification is frequently confirmed through color monitoring, melting point and solid fat profile. The fastest techniques to control are the monitoring of brown color and melting point, but only when melting point alterations exists. The development of brown color is only a tool to verify the reaction, but the complete re-arrangement is dependent of many factors, like catalyst choice, reaction temperature, oil quality (Laning, 1985, Gioielli and Barufaldi, 1988, Erickson, 1995).

The solids profile is the main tool to the specification of fats used in margarine and fat products. The reading must be done at 4 temperatures at least, like $10,20,30$ and $35^{\circ} \mathrm{C}$ or like 20, 30, 35 and $40^{\circ} \mathrm{C}$ (Young, 1985).

The crystals amount in oil mixtures, determined by solid fat content, is responsible for many characteristics of the products, that include general appearance, organoleptic properties, spread facilities and oil exudation (Lida and Ali, 1998).

The solid fat content between $4^{\circ} \mathrm{C}$ and $10^{\circ} \mathrm{C}$ determines the spread facilities of the product at refrigeration temperature. The solids content at up to $32 \%$ at $10^{\circ} \mathrm{C}$, is essential to guarantee good performance of spread at refrigeration temperature (Lida and Ali, 1998).

The solid fat content between 20 and $22^{\circ} \mathrm{C}$ determines the product stability and its resistance against oil exudation. The ideal solid contents must be at least $10 \%$. Between 35 and $37^{\circ} \mathrm{C}$ it determines the softness and smell properties in the mouth (Lida and Ali, 1998). 
The solid profile has a good relation with hardness characteristics of plastic fats and contributes with the structure of final product (Woerfel, 1995).

Shortenings with small solid variation in a wide temperature range are defined as plastic fats. This plasticity is desirable in many products, as margarines and chocolates and can be used under several temperatures where aeration and crystalline structure at high temperatures are important. The plasticity range is less important in products used under controlled conditions or in melting state, like in frying (Woerfel,1995).

In some systems that contain fats, it is desirable a high solid content to promote an adequate crystalline structure in foods with a high content of fats, like margarines and chocolate under room temperature and low solid content in high temperatures, to promote an easy melting in the mouth (Woerfel,1995).

By definition, texture is a hardness measure of a product in a specified temperature. The consistency variation in a temperature range is defined as plasticity (Erickson, 1995). Texture, measured as consistency or plasticity, is one of the most important characteristics of fat products and is primarily determined through physical properties of fats and oils (Lida and Ali, 1998).

In margarines, texture appears as a very important parameter, because these products should have good spread properties under refrigeration and do not settle oils when leaved under room temperatures (Deman et al., 1991).

Texture and spreadability depends on two main factors, that include a solid fat content and process conditions during the cooling and crystallization of emulsion (List et al., 1995). The yield value parameter was described by (Haighton, 1959), and is considered as an independent parameter. The yield value is used to compare the several hardness index, obtained by penetrometers and other reological instruments.

The yield values in commercial margarines that were produced with hydrogenated soybean oil or mixtures of liquid and hydrogenated oils showed values from $200 \mathrm{~g} . \mathrm{cm}^{-1}$ for soft products until 2800 g.cm ${ }^{-1}$ for hard products (List et al., 1995).

The values that influence yield value and must be considered are: softness and cone format, structural hardness, penetration time and kinetic energy of the cone (Haighton, 1959).

\section{EXPERIMENTAL}

\subsection{Material}

Refined palm oil (PO) and palm kernel oil (PKO), supplied by Companhia Refinadora da Amazônia (CRA), Brazil.

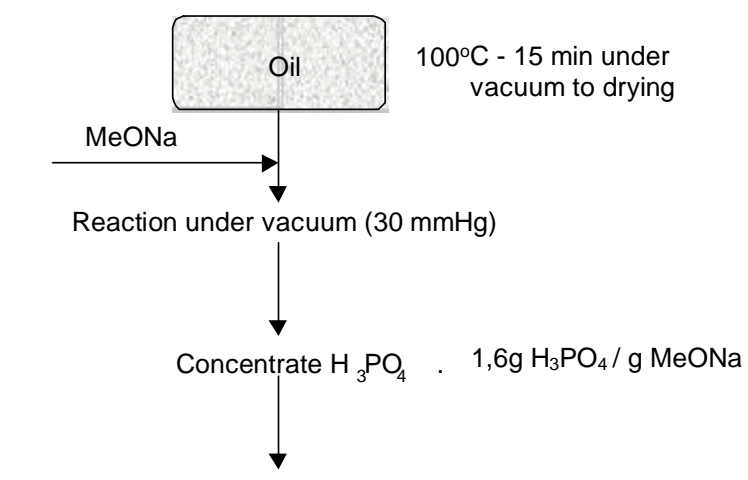

3 washes with $10 \%$ hot water $\left(90^{\circ} \mathrm{C}\right)-10 \mathrm{~min}$.

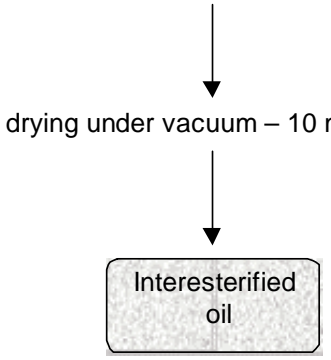

Figure 1

Chemical interesterification reaction scheme.

PO/PKO mixtures (\%) - 100/0, 80/20, 60/40, $50 / 50,40 / 60,20 / 80,0 / 100$ before and after interesterification reaction in the following conditions: $0.4 \% \mathrm{MeONa}, 100^{\circ} \mathrm{C}, 20$ minutes. (Figure 1).

Sodium methoxide, supplied by BASF S.A.

\subsection{Methods}

Free fatty acids - Method AOCS Ca 5a-40 (96)

Moisture and Volatile Matter - Method AOCS Ca 2c-25 (96)

Peroxide Value - Method AOCS Cd 8-53 (96)

Soap - Method AOCS Cc 17-79 (96) (96)

Fatty acid composition - Method AOCS Ce 1c-89

Esterification - Method Hartman \& Lago (1973).

Analysis conditions: Perkin Elmer Sigma 3B Chromatograph

Operation conditions:

Capillary column - fused silica CP-Sil-88, $50 \mathrm{~m} \mathrm{x}$ $0,25 \mathrm{~mm}$ id., $0,2 \mu \mathrm{m}$ film (Crompack). Oven temperature $-180^{\circ} \mathrm{C}-15$ min., $180-200^{\circ} \mathrm{C}-1^{\circ} \mathrm{C} /$ min; $200^{\circ} \mathrm{C}-10 \mathrm{~min}$; Detector: $300^{\circ} \mathrm{C}$; injector: $270^{\circ} \mathrm{C}$; Carrier gas $(\mathrm{He})-0.98 \mathrm{~mL} / \mathrm{min}$; Split -1:115.

Solid Fat Content: pNMR technique Minispec Bruker PC 120. Method AOCS Cd 16b-93 (1996). Serial procedure.

Texture: Texture Analyzer TA-XT2 (Stable Micro Systems), controlled by computer. The compression values were converted to yield value, in accord to Haighton (1959). 
Sample preparation: the fats were melted and tempered during 24 hours at reading temperature $\left(10,20,25,30\right.$ and $\left.35^{\circ} \mathrm{C}\right)$.

\section{RESULTS AND DISCUSSION}

The normal solid profile behavior after chemical interesterification reaction between palm and palm kernel mixtures showed a consistency increase to samples with a high palm oil content and a consistency decreased to palm kernel oil (Laning, 1985). Allen (1996) cited that normally the interesterification is accomplished with a mixture of two oils and for some products that require a high consistency they can absorb in their formulation hydrogenated oils. Chemical specifications of raw materials and solid fat content of PO/PKO mixtures before and after interesterification can be visualized at Tables I and II.

The composition that contain up to $60 \%$ of PKO showed a consistency increase. In other fractions, with 80 and $100 \%$ of PKO, the solid profile was lower. The desirable product must contain an intermediate solid content in a wide temperature range. The interesterification modify some melting properties and influence the velocity and morphology of crystals formation (Laning, 1985).

Palm kernel oil interesterified with small proportions of palm oil can be used in the preparation of coatings with good texture, without fragility at room temperature and with good melting properties (Goh, 1994).

Table I

Analytical characteristics and fatty acid composition of palm (PO) and palm kernel oils (PKO)

\begin{tabular}{|c|c|c|c|}
\hline \multicolumn{2}{|c|}{ Characteristics } & PO & PKO \\
\hline \multicolumn{2}{|c|}{ Moisture and volatile matter(\%) } & 0.04 & 0.04 \\
\hline \multicolumn{2}{|c|}{$\begin{array}{c}\text { Free fatty acids (\% as palmitic acid to } \\
\text { PO and \% as lauric acid to PKO) }\end{array}$} & 0.08 & 0.06 \\
\hline \multicolumn{2}{|c|}{ Peroxide value (meq $\mathrm{O}_{2} / \mathrm{Kg}$ sample) } & 0 & 0 \\
\hline \multicolumn{2}{|c|}{ Soap (mg/Kg) } & 0 & 0 \\
\hline \multicolumn{2}{|c|}{ Fatty acid } & PO & PKO \\
\hline $\mathrm{C} 8: 0$ & Caprylic & - & 4.9 \\
\hline C10:0 & Capric & - & 4.0 \\
\hline C12:0 & Lauric & 1.1 & 45.8 \\
\hline C14:0 & Myristic & 1.0 & 15.1 \\
\hline C16:0 & Palmitic & 40.7 & 9.2 \\
\hline C18:0 & Stearic & 5.0 & 2.4 \\
\hline C18:1 & Oleic & 42.0 & 16.1 \\
\hline C18:2 & Linoleic & 10.2 & 2.5 \\
\hline
\end{tabular}

Table II

Solid fat content (\%) of PO/PKO mixtures before and after interesterification

\begin{tabular}{ccccccccc}
\hline \multicolumn{7}{c}{ Before interesterification } \\
\hline${ }^{\circ} \mathrm{C}$ & $100 / 0$ & $80 / 20$ & $60 / 40$ & $50 / 50$ & $40 / 60$ & $20 / 80$ & $0 / 100$ \\
\hline 10 & 36.02 & 33.44 & 38.19 & 43.85 & 47.16 & 55.95 & 61.9 \\
20 & 13.08 & 9.23 & 8.34 & 14.44 & 17.23 & 27.41 & 37.1 \\
25 & 10.07 & 7.69 & 4.61 & 3.52 & 3.88 & 8.64 & 16.82 \\
30 & 6.95 & 5.32 & 2.49 & 2.3 & 1.45 & 0 & 0 \\
35 & 3.3 & 2.2 & 0.66 & 0.19 & 0 & & \\
40 & 1.62 & 0 & 0 & 0 & & & \\
45 & 0 & & & & & & \\
\hline \multicolumn{7}{c}{0} & \multicolumn{7}{c}{ After interesterification } & & \\
\hline${ }^{\circ} \mathrm{C}$ & $100 / 0$ & $80 / 20$ & $60 / 40$ & $50 / 50$ & $40 / 60$ & $20 / 80$ & $0 / 100$ \\
\hline 10 & 39.69 & 38.05 & 38.21 & 42.43 & 44.82 & 51.98 & 59.06 \\
20 & 19.45 & 18.62 & 17.4 & 19.19 & 19.19 & 23.19 & 26.87 \\
25 & 16.16 & 14.74 & 10.89 & 10.67 & 9.74 & 7.69 & 7.12 \\
30 & 13.41 & 9.25 & 4.85 & 3.11 & 2.16 & 0.17 & 0 \\
35 & 7.03 & 3.71 & 0.22 & 0 & 0 & 0 & \\
40 & 3.79 & 0 & 0 & & & & \\
45 & 1.08 & & & & & & \\
\hline
\end{tabular}

Mean of standard deviations observed at each temperature - \pm 0.2 (solid fat content value).

Figures 2 and 3 show isosolid diagrams of palm and palm kernel oils compositions before and after interesterification. (Lefebvre, 1983) cited that isosolids curves can be used to prove an eutectic system in oil mixtures. These diagrams represent under constant temperature, the solid content of several PO/PKO compositions (Rousseau et al., 1996).

The behavior alteration in an isosolid profiles before and after interesterification characterizes the eutectic system formation. (Balbo and Gioielli, 1991) demonstrate that an efficient way to visualize an eutectic system is the depression curve, that was minimized after interesterification. (Young, 1985) cited that this softness effect can be useful in some cases, like in margarines obtained with palm and palm kernel oils mixtures. By the other side, the incompatibility between cocoa butter and substitutes promotes structure crystalline modification and softness of chocolate during the storage (Lannes and Gioielli, 1995).

The texture values, represented by yield value showed similar behavior that solid profiles. The consistency improve was noted at $40 / 60$ fraction after interesterification and at $25^{\circ} \mathrm{C}$ a high consistency improvement was detected, that contributes to a better plasticity. 


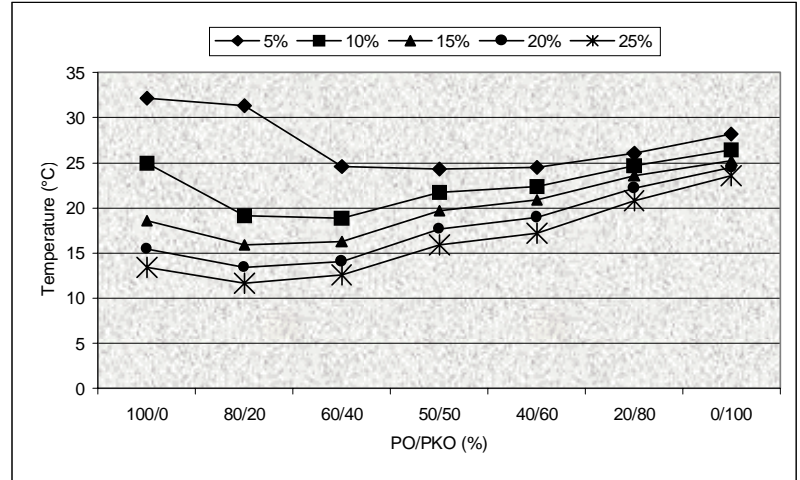

Figure 2

Isosolid curves of binary mixtures of PO/PKO before interesterification.

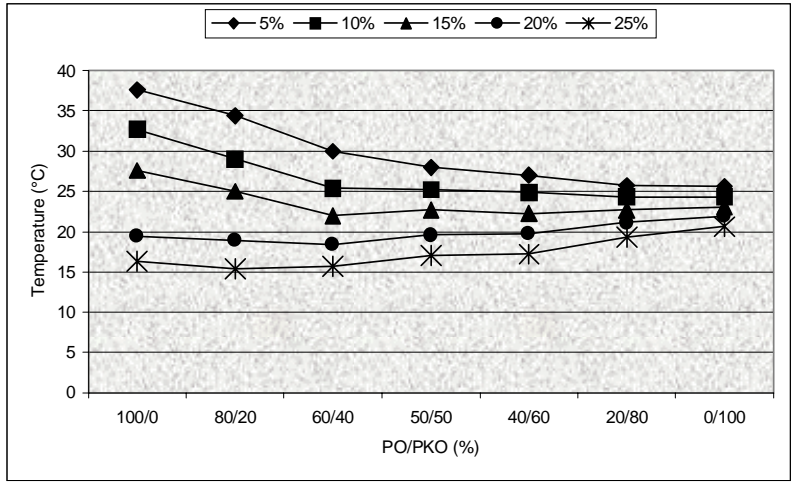

Figure 3

Isosolid curves of binary mixtures of PO/PKO after interesterification.

The eutectic effect was proved through yield values. This effect can be best visualized by consistency decreased at $20^{\circ} \mathrm{C}$ of the samples before interesterification at $80 / 20,60 / 40$ and $50 / 50$ fractions. The Table III shows the yield values obtained for PO/PKO fractions.

The isoconsistency curve (Figures 4 and 5) is another way to visualize this effect.

The linearity absence at the evaluated range is cited as an important aspect to identify eutectic system. To the mixture of two components, (Hare, 1974) describes a mathematical model based on quadratic answer to solid fat index (SFI) values and that the factors are dependent, contrary to factorial experimental, where one of the factors can be varied independently.

The increase of linearity, observed at $80 / 20$ and $60 / 40$ fractions, after interesterification is an evidence that the technological process decreased the incompatibility and that this mixtures can reach more industrial applications than the original ones.
Table III

Yield value $\left(\mathrm{g} . \mathrm{cm}^{-1}\right)$ of PO/PKO mixtures before and after interesterification.

\begin{tabular}{cccccccc}
\hline \multicolumn{7}{c}{ Before interesterification } \\
\hline${ }^{\circ} \mathrm{C}$ & $\mathbf{1 0 0 / 0}$ & $\mathbf{8 0 / 2 0}$ & $\mathbf{6 0 / 4 0}$ & $\mathbf{5 0 / 5 0}$ & $\mathbf{4 0 / 6 0}$ & $\mathbf{2 0 / 8 0}$ & $\mathbf{0} / 100$ \\
\hline 10 & 8740.8 & 8522.9 & 10454.9 & 12541.1 & 10561.6 & 13780.7 & 10481.6 \\
20 & 1027.5 & 449.3 & 489.3 & 1090.3 & 1926.1 & 3902.6 & 6743.5 \\
25 & 146.8 & 130.5 & 28.2 & 31.1 & 89 & 269.9 & 1118 \\
30 & 0 & 0 & 0 & 0 & 0 & 0 & 0 \\
\hline \multicolumn{7}{c}{ After interesterification } \\
\hline${ }^{\circ} \mathrm{C}$ & $100 / 0$ & $80 / 20$ & $60 / 40$ & $50 / 50$ & $40 / 60$ & $\mathbf{2 0 / 8 0}$ & $\mathbf{0} / 100$ \\
\hline 10 & 9093.7 & 7363.3 & 8634.1 & 9712 & 10204.3 & 8946.2 & 16316.2 \\
20 & 1206.9 & 2281.9 & 3058.9 & 2769.8 & 3635.7 & 2670.4 & 4307.4 \\
25 & 579.8 & 587.2 & 793.3 & 591.6 & 444.8 & 315.8 & 283.2 \\
30 & 143.8 & 115.7 & 94.9 & 51.9 & 111.2 & 0 & 0 \\
35 & 71.2 & 0 & 40 & 0 & 0 & & 0 \\
\hline
\end{tabular}

Mean of standard deviations observed at each temperature - $\pm 6 \%$ (yield value content).

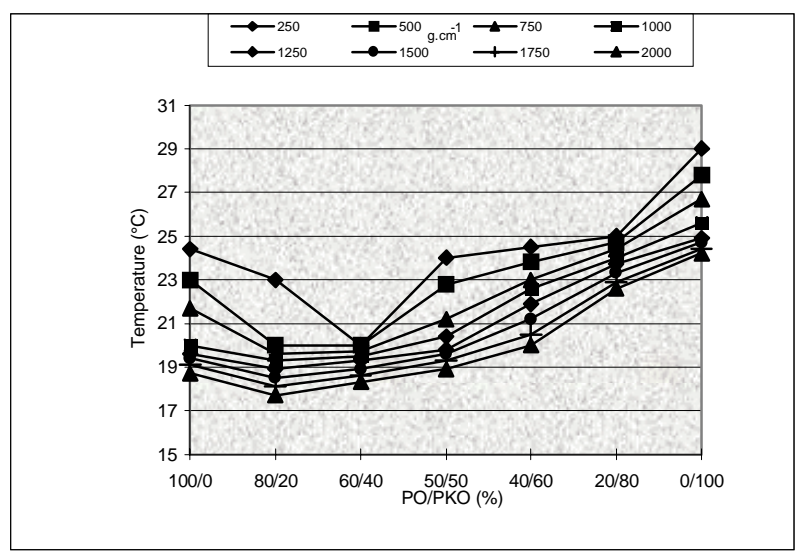

Figure 4

Isoconsistency curves of binary mixtures of PO/PKO before interesterification.

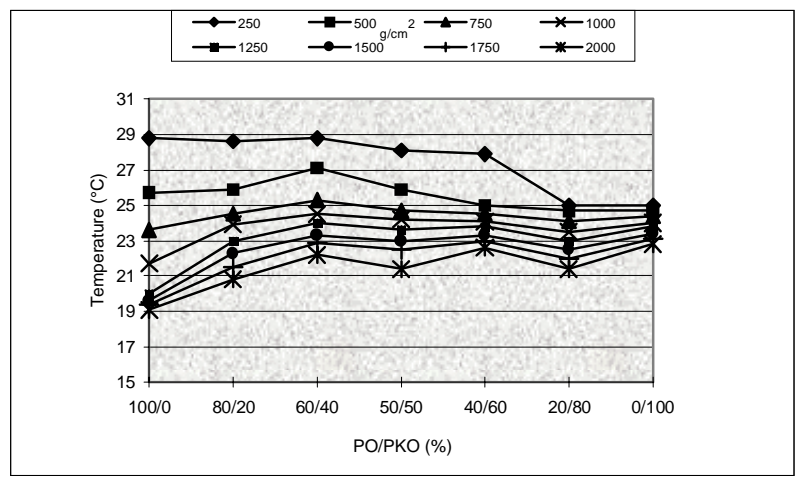

Figure 5

Isoconsistency curves of binary mixtures of $\mathrm{PO} / \mathrm{PKO}$ after interesterification. 
The Tables IV and V present the mathematical models of interactions to mixtures between two components and their correlation, according to (Hare, 1974).

The mathematical model, calculated by multiple regression for two components, according to (Hare, 1974) is the following:

$$
Y=\beta_{1} X_{1}+\beta_{2} X_{2}+\beta_{1.2} X_{1} \cdot X_{2}
$$

Where $\mathrm{Y}$ is the estimated solid fat content or yield value, $X_{1}$ is palm oil proportion, $X_{2}$ is palm kernel oil proportion. $X_{2}+X_{1}=100$. The $R^{2}$ is used to estimate the adjustment of the mathematical model for the to obtained data.

The statistics evaluation, with high correlation values $\left(R^{2}\right)$ evidenced the perfect adjustment of mathematical model for the obtained data. To solid fat

Table IV

Interactions between PO/PKO mixtures before interesterification. Solid fat content (SFC) and «yield value» values

\begin{tabular}{|c|c|c|c|c|}
\hline \multirow[b]{2}{*}{ SFC } & \multicolumn{3}{|c|}{ Coefficients } & \multirow[b]{2}{*}{$\mathrm{R}^{2}$} \\
\hline & $\beta_{1}$ & $\beta_{2}$ & $\beta_{12}$ & \\
\hline $10^{\circ} \mathrm{C}$ & 34.14 & 63.55 & -24.20 & 0.99837 \\
\hline $20^{\circ} \mathrm{C}$ & 12.18 & 38.40 & -47.83 & 0.99446 \\
\hline $25^{\circ} \mathrm{C}$ & 11.11 & 16.24 & -38.57 & 0.98867 \\
\hline Yield Value & $\beta_{1}$ & $\beta_{2}$ & $\beta_{12}$ & $\mathrm{R}^{2}$ \\
\hline $10^{\circ} \mathrm{C}$ & $7.95 \times 10^{3}$ & $1.15 \times 10^{4}$ & $6.80 \times 10^{3}$ & 0.98833 \\
\hline $20^{\circ} \mathrm{C}$ & $1.02 \times 10^{3}$ & $6.79 \times 10^{3}$ & $-1.11 \times 10^{4}$ & 0.99926 \\
\hline $25^{\circ} \mathrm{C}$ & 239.47 & $1.00 \times 10^{3}$ & $-2.41 \times 10^{3}$ & 0.94166 \\
\hline
\end{tabular}

Table V

Interactions between PO/PKO mixtures after interesterification. Solid fat content (SFC) and «yield value» values

\begin{tabular}{ccccc}
\hline & \multicolumn{5}{c}{ Coefficients } & \\
\cline { 2 - 4 } SFC & $\beta_{1}$ & $\beta_{2}$ & $\beta_{12}$ & $\mathbf{R}^{2}$ \\
\hline $10^{\circ} \mathrm{C}$ & 39.13 & 59.88 & -30.76 & 0.99955 \\
$20^{\circ} \mathrm{C}$ & 19.57 & 27.08 & -18.46 & 0.99946 \\
$25^{\circ} \mathrm{C}$ & 16.55 & 6.90 & -4.82 & 0.99827 \\
\hline Yield Value & $\beta_{1}$ & $\beta_{2}$ & $\beta_{12}$ & $\mathbf{R}^{2}$ \\
\hline $10^{\circ} \mathrm{C}$ & $9.07 \times 10^{3}$ & $1.51 \times 10^{4}$ & $-1.37 \times 10^{4}$ & 0.98474 \\
$20^{\circ} \mathrm{C}$ & $1.40 \times 10^{3}$ & $3.87 \times 10^{3}$ & $1.43 \times 10^{3}$ & 0.97679 \\
$25^{\circ} \mathrm{C}$ & 597.25 & 219.30 & 702.65 & 0.97262 \\
\hline
\end{tabular}

content at 20 and $25^{\circ} \mathrm{C}$, the decrease of $\beta_{1.2}$ values is an indication that the reaction contributed to decrease the incompatibility.

\section{CONCLUSION}

Palm and palm kernel fractions showed characteristics of eutectic system, mainly at 80/20 and 50/50 PO/PKO fractions. The chemical interesterification at $100^{\circ} \mathrm{C}$ and 20 minutes with $0,4 \%$ of sodium methoxide minimized the incompatibility between the fractions and improved the plasticity.

The use of binary systems $\mathrm{PO} / \mathrm{PKO}$ after interesterification, mainly in levels of $20-50 \%$ of $\mathrm{PKO}$, showed a great promise in terms of industrial process at products with a low isomers trans content. The results obtained can be compare with characterization done by (Grimaldi, et al., 2000) with commercial shortenings. These mixtures could be used like ingredients for bakery products and ice cream that exhibit similar melting profiles with the advantage that contain a low trans isomers content in their formulation.

\section{ACKNOWLEDGEMENTS}

The authors would like to express many thanks to FAPESP - Fundação de Amparo à Pesquisa do Estado de São Paulo by the financial support and to CRA (Companhia Refinadora da Amazônia) by the supplier of palm and palm kernel oils.

\section{REFERENCES}

Allen, D.A. (1996). Interesterification - a vital tool for the future. Lipid Technol. 1, 11-18.

AOCS (1997). Official Methods and Recommended Practices of the American Oil Chemist's Society. Champaign, v.1-2.

Balbo, A.M.T.M. and Gioielli, L.A. (1991). Mixtures of babassu fat with palm oil and its fractions: eutetic interactions. International Meeting of Fats \& Oils Technology, 184-188, UNICAMP/GTZ (Ed.), Campinas.

Deman, L., Man, J.M. and Blackman, B. (1991). Physical and textural characteristics of some North American shortenings. J. Am. Oil Chem. Soc. 68, 63-69.

Erickson, M.D. (1995). Interesterification. IN: Erickson, D.R. Practical handbook of soybean processing and utilization. Chap.16, 277-296, AOCS Press (Ed), Champaign.

Gioielli,L.A.; Barufaldi, R. (1988). Acompanhamento da reação de interesterificação de gordura de babaçu e azeite de dendê. Rev. Farm. e Bioq. da USP, 24, 29-38.

Goh,E.M. (1994). Formulation of lauric oil-containing food products and their performance. World Conference On Lauric Oils; Sources, Processing And Applications. 98-103, AOCS Press (Ed.), Champaign.

Grimaldi, R.; Gonçalves, L.A.G.; Esteves, W. (2000). Características de gorduras comerciais brasileiras. Brazil. J. Food Technol., 3, 159-164. 
Haighton, A.J. (1959). The measurements of the hardness of margarine and fats with cone penetrometers. J. Am. Oil Chem. Soc., 36, 345-348.

Hare, L.B. (1974). Mixture designs applied to food formulation. Food Technol., 28 (3), 50-62.

Hartmann, L.; Lago, R. (1973). Rapid preparation of fatty acid methyl esters from lipids. Lab. Pract., 22, 475-476.

Lannes, S.C.S.; Gioielli, L.A. (1995). Misturas entre manteiga de cacau e sucedâneos comerciais: estudo de diagramas de curvas de iso-sólidos e de iso-consistência. Ciência e Tecnol. de Alim., 15, 132-137.

Laning,S.J. (1985). Chemical interesterification of palm, palm kernel and coconut oils. J. Am. Oil Chem. Soc., 62, 400-407.

Lefebvre, J. (1983). Finished product formulation. J. Am. Oil Chem. Soc., 60, 295-300.

Lida, H.M.D.N.; Ali, A.R.M. (1998). Physicochemical characteristics of palm-based oil blends for the production of reduced fat spreads. J. Am. Oil Chem. Soc., 75, 1625-1631.

List, G.R.; Mounts, T.L. Orthoefer, F.; Neff, W.E. (1995). Margarine and shortening oils by interesterification of liquid and trisaturated triglycerides. J. Am. Oil Chem. Soc., 72, 379-382.

Rousseau, D.; Forestière, K.; Hill, A.R.; Marangoni, A.G. (1996). Restructuring butterfat through blending and chemical interesterification. 1.Melting behavior and triacylglicerol modifications. J. Am. Oil Chem. Soc., 73, 963-972.

Young, F.V.K. (1985). Interchangeability of fats and oils. J. Am. Oil Chem. Soc., 62, 372-376.

Woerfel,J.B. (1995). Formulation of soy oil products. Grasas Aceites, 46, 357-365.

Recibido: Septiembre 2000 Aceptado: Mayo 2001 